\title{
KEMAMPUAN $\mathrm{Ca}(\mathrm{OH})_{2}$ MENURUNKAN KADAR $\mathrm{SO}_{2}$ PADA EMISI GAS BUANG MOTOR DIESEL.
}

Merlita Novia Veronica, S.B Ekowarno, Rachmaniyah

\begin{abstract}
Sulfur dioxide is a major constituent of exhaust gas generated by diesel engines. The main impact of SOx ( $\mathrm{SO}_{2}$ and $\mathrm{SO} 3$ ) contaminant is the generation of very sharp odor, the eventual occurrence of corrosive acid rain, where as to humans such contaminants may cause irritation to eyes, skin and repiratory systems, and may prove to be fatal.

The final product chemical reaction, $\mathrm{H}_{2} \mathrm{SO}_{4}$ may cause corrosiveness, acid rain, and irritation to the eyes, skin, and respiratory tract, and may even be fatal, therefore it is deemed necessary to initiate control of exhaust emissions from diesel engines. One of the many methods is the use of a saturated solution of lime water $(\mathrm{CaOH} 2)$ as absorbent to reduce the said emissions.

The purpose of this study was to determine the capacity of a saturated aqueous solution of lime or $\mathrm{Ca}(\mathrm{OH}) 2$ in lowering the levels of $\mathrm{SO} 2$ in the flue gas emission from diesel engines (mobile sources).

This is a pre-experimental study using One Group Pre-Post Test Design, this study was carried out by conducting measurements on 6 samples of diesel engine exhaust emissions where 2 (two) measurements were done before and 4 (four) samples after passing through saturated lime water absorbent $(\mathrm{CaOH} 2)$. Duration of sampling ranged between $20-25$ minutes.

The results indicated the average levels of SOx before passing through saturated lime water $(\mathrm{CaOH} 2)$ was $117,355 \mathrm{mg} / \mathrm{m} 3$ and the mean level of $\mathrm{SO} 2$ after passing through a saturated lime water was $79,90 \mathrm{mg} / \mathrm{m} 3$. There was a decline in the average levels of SO2 at a value of $37,455 \mathrm{mgr} / \mathrm{m} 3$ or by $31,90 \%$

This study concluded, that the lime water $(\mathrm{CaOH} 2)$ solution was able to reduce the level of SO2 in exhaust emissions of a diesel engines by $37,455 \mathrm{mgr} / \mathrm{m} 3$ or $31,90 \%$.

It is suggested to owners of diesel engine motor vehicles to always perform proper maintenance of their vehicles, and citizens (especially those living on the outskirt of a highway), in order to help preserving the environment, are expected to plant trees and various other plants that can absorb contaminants or can be used as indicators of pollution by motor vehicle exhaust emissions. The study also recommended to study other kinds of pollutant gases.
\end{abstract}

Keywords : $\mathrm{Ca}(\mathrm{OH})_{2}, \mathrm{SO}_{2,}$, Diesel exhaust emissions

\section{PENDAHULUAN \\ Latar Belakang \\ Semakin \\ meningkatnya aktivitas manusia, semakin meningkat pula tingkat pencemaran udara yang dihasilkan (Mulia, 2005). Menurut Harssema (1998), pencemaran udara diawali oleh adanya emisi yang dapat disebabkan oleh proses alam maupun kegiatan manusia terutama dari kegiatan transportasi yang menggunakan bahan bakar solar. Proses pembakaran pada motor diesel yang menggunakan bahan bakar solar akan menghasilkan $\mathrm{SO}_{\mathrm{x}}$ (sulfur dioksida dan sulfur trioksida) dengan perbandingan $30: 1$. Yang berarti, bahwa sulfur dioksida merupakan bagian yang sangat dominan dalam gas buang motor diesel. (Arifin Zainal dan Sukoco, 2009). \\ Pengaruh utama polutan $\mathrm{SO}_{x}$ terhadap lingkungan adalah timbulnya bau yang sangat tajam, terjdinya korosif pada logam dan hujan}

asam, sedang pada manusia dapat menyebabkan terjadinya iritasi pada mata, kulit dan iritasi sistem pernafasan, bahkan kematian. Beberapa penelitian menunjuk kan bahwa iritasi tenggorokan terjadi pada konsentrasi $\mathrm{SO}_{2}$ sebesar $8 \mathrm{ppm}$ atau lebih, bahkan pada beberapa individu yang sensitif iritasi terjadi pada konsentrasi 1-2 ppm. $\mathrm{SO}_{2}$ dianggap polutan yang berbahaya bagi kesehatan terutama terhadap orang tua dan penderita yang mengalami penyakit kronis pada sistem pernafasan dan kardiovaskuler. Seperti yang terjadi di lembah sungai Nerse Belgia pada tahun 1930 tingkat kandungan $\mathrm{SO}_{2}$ di udara mencapai $38 \mathrm{ppm}$ dan menyebabkan toksisitas akut. Pada tahun 1952 di London, selama 5 hari terjadi perubahan temperatur dan pembentukan kabut yang menyebabkan kematian 3500-4000 penduduk, peristiwa ini dikenal dengan "London Smog". 
Hasil autopsi menyatakan bahwa kematian disebabkan oleh iritasi saluran pernafasan. (Mulia, 2005)

Akibat dari pencemaran yang ditimbulkan oleh $\mathrm{SO}_{2}$, maka perlu dilakukan pengendalian emisi gas buang motor diesel, dengan cara menggunakan larutan air kapur atau $\mathrm{Ca}(\mathrm{OH})_{2}$ sebagai penyerap untuk menurunkan kadar $\mathrm{SO}_{2}$ pada emisi gas buang motor diesel sumber bergerak.

\section{Tujuan Penelitian}

Mengetahui kemampuan air .kapur atau $\mathrm{Ca}(\mathrm{OH})_{2}$ jenuh menurunkan kadar sulfur dioksida $\left(\mathrm{SO}_{2}\right)$ pada emisi gas buang motor diesel sumber bergerak.

\section{METODE PENELITIAN}

\section{HASIL PENELITIAN DAN PEMBAHASAN}

HASIL

1. Kadar $\mathrm{SO}_{2}$ Sebelum dan Sesudah Melalui Air Kapur

Pada pengukuran sampel sebelum dan sesudah melalui larutan air kapur $\left(\mathrm{CaOH}_{2}\right)$ jenuh, dengan kecepatan alir udara $15 \mathrm{~L} /$ menit dan temperatur mesin motor diesel sumber bergerak $53^{\circ} \mathrm{C}$. didapatkan kadar $\mathrm{SO}_{2}$ seperti pada table 1 .

Tabel.1

KADAR $\mathrm{SO}_{2}$ SEBELUM DAN SESUDAH MELALUI AIR KAPUR $\left(\mathrm{mgr} / \mathrm{M}^{3}\right)$

\begin{tabular}{|c|c|c|c|c|}
\hline Tanggal & Jam & $\begin{array}{c}\text { Kadar } \\
\text { Sebelum }\end{array}$ & $\begin{array}{c}\text { Waktu } \\
\text { Kontak } \\
\text { (menit) }\end{array}$ & $\begin{array}{c}\text { Kadar } \\
\text { Sesudah }\end{array}$ \\
\hline $14-5-1013$ & 13.54 & 125,63 & 0 & - \\
\hline & 15.50 & 109,08 & 0 & - \\
\hline $14-5-1013$ & 14.25 & & 31 & 97,36 \\
\hline $14-5-1013$ & 14.51 & & 57 & 84,21 \\
\hline $14-5-1013$ & 15.10 & & 76 & 75,15 \\
\hline $14-5-1013$ & 15.30 & & 96 & 62,88 \\
\hline Rerata & & $\mathbf{1 1 7 , 3 5 5}$ & $\mathbf{6 5}$ & $\mathbf{7 9 , 9 0}$ \\
\hline
\end{tabular}

2. Hasil pengukuran

a. Kadar rerata $\mathrm{SO}_{2}$ pada emisi gas buang motor diesel sumber bergerak sebelum melalui air kapur sebesar 117,355 $\mathrm{mg} / \mathrm{M}^{3}$.

b. Kadar rerata $\mathrm{SO}_{2}$ pada emisi gas buang motor diesel sumber bergerak sesudah melalui air kapur sebesar 79,9 mg/ $\mathrm{M}^{3}$.

c. Dari hasil pengukuran di dapat perbedaan kadar rerata $\mathrm{SO}_{2}$ pada emisi
Jenis penelitian

Jenis penelitian ini pra eksperimen dengan desain One Group Pre-Post Test Design.

\section{Lokasi penelitian}

Dilakukan di bengkel kerja dan laboratorium prodi kesehatan lingkungan Surabaya, Jl. Menur 118 A Surabaya.

\section{Obyek penelitian}

Adalah emisi gas buang motor diesel sumber bergerak.

\section{Hipotesis :}

Dikatakan terbukti jika ada penurunan kadar $\mathrm{SO}_{2}$ pada pemeriksaan sampel setelah melalui air kapur $\left(\mathrm{CaOH}_{2}\right)$ jenuh. 
Perhitungan efisiensi:

$$
\text { Efisiensi }(\%)=\frac{\text { Kadar } 502 \text { sebelum }- \text { Kadar SO2 sezudah }}{\text { Kadar SO2 sebel um }} \times 100 \%
$$

Tabel.2

EFISIENSI ABSORBEN MEREDUKSI $\mathrm{SO}_{2}$

\begin{tabular}{|c|c|c|c|c|}
\hline \multicolumn{2}{|c|}{ Waktu sampling } & \multirow{2}{*}{$\begin{array}{c}\text { Kadar } \mathrm{SO}_{2} \\
\text { sebelum melalui } \\
\text { air kapur }\left(\mathrm{mg} / \mathrm{m}^{3}\right)\end{array}$} & \multirow{2}{*}{$\begin{array}{l}\text { Kadar } \mathrm{SO}_{2} \text { sesudah } \\
\text { melalui air kapur } \\
\left(\mathrm{mg} / \mathrm{m}^{3}\right)\end{array}$} & \multirow{2}{*}{ Efisiensi (\%) } \\
\hline Tanggal & Jam & & & \\
\hline $\begin{array}{c}14 \mathrm{Mei} \\
2013\end{array}$ & $\begin{array}{l}14.25 \\
14.51 \\
15.10 \\
15.30\end{array}$ & $\begin{array}{l}117,355 \\
117,355 \\
117,355 \\
117,355\end{array}$ & $\begin{array}{l}97,36 \\
84,21 \\
75,15 \\
62,88\end{array}$ & $\begin{array}{c}17 \% \\
28,24 \% \\
35,96 \% \\
46,41 \%\end{array}$ \\
\hline Rata & & 117,355 & 79,9 & $31,90 \%$ \\
\hline
\end{tabular}

Efisiensi penurunan paling rendah terjadi pada percobaan pertama pada jam 14.25 sebesar $17 \%$. Sedangkan penurunan paling tinggi terjadi pada percobaan keempat pada jam 15.30 sebesar $46,41 \%$.

\section{PEMBAHASAN}

\section{A. Kadar $\mathrm{SO}_{2}$ Pada Emisi Gas Buang Motor Diesel Sebelum dan Sesudah Melalui Air Kapur.}

1. Proses absorbsi $\mathrm{SO}_{2}$ dengan air kapur Proses absorbsi oleh $\mathrm{SO}_{2}$ dibagi menjadi dua tahap yaitu absorpsi fisik, ketika gas diserap ke dalam air kapur, absorbsi kimia ketika komponen yang telah diserap bereaksi dengan air kapur.

Pada tahap absorbsi fisik, $\mathrm{SO}_{2}$ akan mengalami proses difusi dari fase gas menuju fase liquid. Pada tahap absorbsi kimia, $\mathrm{SO}_{2}$ bergerak menuju fase liquid. Secara keseluruhan reaksi yang terjadi adalah sebagai berikut :

$$
\begin{aligned}
& \mathrm{CaCO}_{3}+\mathrm{H}_{2} \mathrm{O} \\
& \mathrm{Ca}(\mathrm{OH})_{2}+\mathrm{CO}_{2}(1) \\
& 2 \mathrm{Ca}(\mathrm{OH})_{2}+2 \mathrm{SO}_{2}+\mathrm{O}_{2} \\
& 2 \mathrm{CaSO}+2 \mathrm{H}_{2} \mathrm{O}(2)
\end{aligned}
$$

Reaksi (1) adalah Kapur atau $\mathrm{CaCO}_{3}$ yang telah dicampur dengan air atau $\mathrm{H}_{2} \mathrm{O}$ hingga menjadi air kapur $\mathrm{Ca}(\mathrm{OH})_{2}$ digunakan sebagai absorben untuk proses pengolahan $\mathrm{SO}_{2}$.

Reaksi (2) adalah Air kapur $\mathrm{Ca}(\mathrm{OH})_{2}$ yang telah bereaksi dengan sulfur dioksida $\mathrm{SO}_{2}$ dan juga $\mathrm{O}_{2}$ atau oksigen mengendap menjadi kalsium sulfat $\mathrm{CaSO}_{4}$ berupa padatan yang berwarna putih.

\section{B. Perbedaan Kadar $\mathrm{SO}_{2}$ Sebelum dan Sesudah Melalui Air Kapur. \\ Pada pelaksanaan pengukuran} didapatkan hasil kadar $\mathrm{SO}_{2}$ sebelum melalui air kapur sebesar $117,355 \mathrm{mg} / \mathrm{m}^{3}$. Sedangkan kadar $\mathrm{SO}_{2}$ setelah melalui air kapur didapatkan rata-rata sebesar $79,9 \mathrm{mg} / \mathrm{m}^{3}$. Berarti ada perbedaan antara kadar $\mathrm{SO}_{2}$ sebelum dengan sesudah melalui air kapur sebesar 37,45 $\mathrm{mg} / \mathrm{m}^{3}$.

Hal disebabkan terjadinya pengendapan $\mathrm{CaSO} 4$ yang terbentuk sebagai hasil reaksi / pengikatan $\mathrm{SO}_{x}$ dengan Air kapur $\mathrm{CaOH}_{2}$ yang dipengaruhi temperatur, dan waktu kontak.

Reaksi :

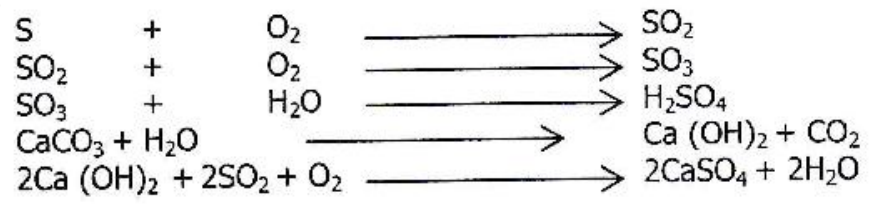




\section{C.Efisiensi Penurunan $\mathrm{SO}_{2}$}

Dari data pengukuran kadar $\mathrm{SO}_{2}$ baik sebelum melalui air kapur maupun setelah melalui air kapur didapatkan prosentase penurunan antara $17 \%-46,41 \%$ dengan rata-rata efisiensi sebesar $31,90 \%$. Perbedaan prosentase penurunan disebabkan karena adanya perbedaan temperature mesin dan lama waktu kontak antara gas $\mathrm{SO}_{x}\left(\mathrm{SO}_{2}\right.$ dan $\left.\mathrm{SO}_{3}\right)$ dengan larutan air kapur $\left(\mathrm{CaOH}_{2}\right)$ jenuh.

\section{KESIMPULAN DAN SARAN}

\section{A. KESIMPULAN}

1) Kadar rerata $\mathrm{SO}_{2}$ pada emisi gas buang motor diesel sumber bergerak sebelum melalui air kapur sebesar $117,355 \mathrm{mg} / \mathrm{m}^{3}$.

2) Kadar rerata $\mathrm{SO}_{2}$ setelah melalui air kapur $79,9 \mathrm{mg} / \mathrm{m}^{3}$.

3) Perbedaan kadar rerata $\mathrm{SO}_{2}$ sebelum melalui air kapur dan sesudah melalui air kapur pada emisi gas buang motor diesel sumber bergerak sebesar $37,45 \mathrm{mg} / \mathrm{m}^{3}$

4) Efisiensi penurunan kadar $\mathrm{SO}_{2}$ pada emisi gas buang motor diesel sumber bergerak rata-rata sebesar $31,90 \%$

\section{B. SARAN}

1. Perlu adanya peran masyarakat untuk mengurangi dampak negatif dari adanya gas sulfur dioksida $\left(\mathrm{SO}_{2}\right)$, dengan cara memelihara kendaraan dan memperbaiki setelan mesin pada motor diesel sumber bergerak agar tidak memberikan dampak $\mathrm{SO}_{2}$ terhadap manusia dan lingkungan.

2. Perlu adanya penelitian lanjutan terhadap parameter lain

3. Melakukan perbaikan lingkungan dengan cara menanam pohon yang dapat dijadikan sebagai penyerab atau petunjuk adanya pencemaran udara khususnya gas $\mathrm{SO}_{x}$

\section{DAFTAR PUSTAKA}

Arifin, Zainal dan Sukoco, 2009. Pengendalian Polusi Kendaraan, Bandung: PT Alfabeta.
B, Kus Dwiyatmo, 2007. Pencemaran Lingkungan dan Penanganannya, Yogyakarta : PT.Citra Aji Parama.

Budijanto, Didik dan Prayoga, 2005. Metodologi Penelitian. Surabaya : Unit Penelitian Dan Pengabdian Masyarakat - Politeknik Kesehatan Surabaya.

Chandra, Budiman, 2007. Pengantar Kesehatan Lingkungan, Jakarta : Buku Kedokteran EGC.

Darmono, 2001.Lingkungan Hidup dan Pencemaran, Jakarta : Universitas Indonesia.

Fardiaz, 1992. Polusi Air dan Udara, Yogyakarta : PT Kanisius.

Hanafiah, Kemas Ali,2011. Rancangan Percobaan Teori dan Aplikasi, Jakarta : Rajawali Pers

Harssema, H, 1998. TEXTBOOK for the course MODELLING AND MONITORING OF AIR QUALTTY, Wageningen : Wageningen Agricultural University.

Kep Men LH no 15 tahun 1996 tentang program langit biru.

Mukono, H.J, 2003. Pencemaran udara dan pengaruhnya terhadap gangguan saluran pernapasan, Surabaya : Airlangga University Press.

Mulia, Ricki M, 2005. Kesehatan Lingkungan, Yogyakarta : PT.Graha IImu.

Peraturan Menteri Lingkungan Hidup Nomor 05 Tahun 2006 tentang ambang batas emisi gas buang kendaraan bermotor lama

Peraturan Menteri Lingkungan Hidup Nomor 04 tahun 2009 tentang ambang batas emisi gas buang kendaraan bermotor.

Peraturan Pemerintah No 41 Tahun 1999 tentang pengendalian pencemaran udara.

Sastrawijaya, Tresna, 2000. Pencemaran Lingkungan, Surabaya : PT Rineka Cipta. 